\title{
Correction to: Overexpression of apelin in Wharton' jelly mesenchymal stem cell reverses insulin resistance and promotes pancreatic $\beta$ cell proliferation in type 2 diabetic rats
}

Lian Ru Gao ${ }^{1}$, Ning Kun Zhang ${ }^{1}$, Yan Zhang ${ }^{1}$, Yu Chen ${ }^{1}$, Li Wang ${ }^{2}$, Ying Zhu ${ }^{1}$ and Hai Hong Tang ${ }^{1 *}$

Correction to: Stem Cell Res Ther

https://doi.org/10.1186/s13287-018-1084-x

The original article [1] contained errors in the presentation of Figure 7 . These have now been corrected.

\section{Author details}

${ }^{1}$ Center of Cardiology, The Sixth Medical Center of P.L.A. General Hospital (Former Navy General Hospital), NO.6 Fucheng Road, Beijing, Haidian District 100048, People's Republic of China. ${ }^{2}$ Department of Internal Medicine, The 413th Hospital of P.L.A., 98 Wenhua Road, Zhoushan, Zhejiang 316000,

People's Republic of China.

Received: 19 December 2018 Revised: 19 December 2018 Accepted: 19 December 2018 Published online: 08 January 2019

\section{Reference}

1. Gao $L R$, et al. Overexpression of apelin in Wharton' jelly mesenchymal stem cell reverses insulin resistance and promotes pancreatic $\beta$ cell proliferation in type 2 diabetic rats. Stem Cell Res Ther. 2018;9:339 https://doi.org/10 1186/s13287-018-1084-X.

\footnotetext{
* Correspondence: Haihong81@163.com

${ }^{1}$ Center of Cardiology, The Sixth Medical Center of P.L.A. General Hospital (Former Navy General Hospital), NO.6 Fucheng Road, Beijing, Haidian District 100048, People's Republic of China

Full list of author information is available at the end of the article
} 